\title{
Review Article \\ DNA-Metallodrugs Interactions Signaled by Electrochemical Biosensors: An Overview
}

\author{
Mauro Ravera, ${ }^{1}$ Graziana Bagni, ${ }^{1,2}$ Marco Mascini, ${ }^{2}$ and Domenico Osella ${ }^{1}$ \\ ${ }^{1}$ Dipartimento di Scienze dell'Ambiente e della Vita, Università del Piemonte Orientale, Via Bellini 25g, \\ 15100 Alessandria, Italy \\ ${ }^{2}$ Dipartimento di Chimica, Università di Firenze, Via della Lastruccia 3, 50019 Sesto Fiorentino Florence, Italy
}

Received 2 April 2007; Accepted 19 June 2007

Recommended by Viktor Brabec

\begin{abstract}
The interaction of drugs with DNA is an important aspect in pharmacology. In recent years, many important technological advances have been made to develop new techniques to monitor biorecognition and biointeraction on solid devices. The interaction between DNA and drugs can cause chemical and conformational modifications and, thus, variation of the electrochemical properties of nucleobases. The propensity of a given compound to interact with DNA is measured as a function of the decrease of guanine oxidation signal on a DNA electrochemical biosensor. Covalent binding at N7 of guanine, electrostatic interactions, and intercalation are the events that this kind of biosensor can detect. In this context, the interaction between a panel of antitumoral Pt-, Ru-, and Ti-based metallodrugs with DNA immobilized on screen-printed electrodes has been studied. The DNA biosensors are used for semiquantitative evaluation of the analogous interaction occurring in the biological environment.
\end{abstract}

Copyright (c) 2007 Mauro Ravera et al. This is an open access article distributed under the Creative Commons Attribution License, which permits unrestricted use, distribution, and reproduction in any medium, provided the original work is properly cited.

\section{INTRODUCTION}

Chemotherapy is an important weapon for combating cancers. Numerous compounds have been developed as potential candidates for anticancer drugs, but only a handful of them have become effective in clinical protocols. The need of developing new drugs in order to effectively treat various forms of cancer is widely recognized. The development of new drugs requires that the underlying mechanism of action at the cellular and molecular levels has been completely understood.

The potential targets for anticancer drugs are essentially four: nucleic acids, specific enzymes, microtubules, and hormone/growth factor receptors. When nucleic acids are the target, the DNA damage causes cell death (cytotoxic and genotoxic drugs).

There are several mechanisms by which drugs can bind DNA [1], the most well understood being alkylation of nucleophilic sites within the double helix. Most clinically effective alkylating agents have two moieties capable of developing transient carbocations that bind covalently to the electron-rich sites on DNA such as the N7 position of guanine (electrophilic agents). The cross-linking of the two strands of DNA produced by the bifunctional alkylating agents prevents the use of that DNA as a template for further DNA and RNA synthesis leading to inhibition of replication and transcription and, then, to cell death. A large number of chemical compounds are alkylating agents under physiologic conditions, and a variety of such compounds have exhibited antitumor activity. To this category belong nitrogen mustards (mechlorethamine, the original "nitrogen mustard," cyclophosphamide, ifosfamide, melphalan, and chlorambucil), aziridines and epoxides (thiotepa, mitomycin $\mathrm{C}$, and diaziquone), alkyl sulfonates (like busulfan and its analogues), nitrosoureas (carmustine, lomustine, and semustine, above all), triazenes, hydrazines, and related compounds. Moreover, also cisplatin and its congeners are traditionally, albeit improperly, considered alkylating drugs.

A second mechanism of drug binding to nucleic acids is intercalation, that is, the insertion of a planar (generally aromatic) ring molecule between two adjacent nucleotides of DNA. This mechanism is characteristic of many antitumor antibiotics, such as daunorubicin and doxorubicin. The antibiotic molecule is noncovalently, although firmly, bound to DNA and distorts the shape of the double helix resulting in inhibition of DNA replication and RNA transcription.

Finally, a third mechanism of DNA damage is illustrated by bleomycins. These glycopeptides intercalate 
between guanine-cytosine base pairs of DNA. The end of the peptide binds $\mathrm{Fe}(\mathrm{II})$, able to catalyze the reduction of molecular oxygen to superoxide or hydroxyl radicals, that produce DNA strand scission by oxidative stress [2].

Due to the stringent relationship between DNA-drug interaction and potential antitumor effect, molecular recognition of nucleic acids by low molecular weight compounds is an area of fundamental interest. A detailed understanding of the interaction of small molecules with DNA is very important in pharmacology.

In this context, cisplatin (cis-diamminedichloroplatinum(II), $\left.\left[\mathrm{Pt}\left(\mathrm{NH}_{3}\right)_{2} \mathrm{Cl}_{2}\right]\right)$ probably represents a milestone in the antitumor chemotherapy. The activity of cisplatin was serendipitously discovered in 1969 by Rosenberg and colleagues while studying the effects of electric current on bacterial growth. Cisplatin entered clinical trials in the early 1970s and was found to have significant antitumor activity against testicular, ovarian, bladder, and head and neck cancer. Because of the nephro- and neuro-toxicity of cisplatin, there have been intensive efforts to devise analogues with similar or improved pharmacological characteristics. Carboplatin, cisdiammine-(1,1-cyclobutanedicarboxylato)platinum(II) (approved worldwide in 1992), shows an antitumor activity similar to that of cisplatin, but with reduced systemic toxicity (better therapeutic index), while oxaliplatin (1R,2R-diaminocyclohexane)oxalatoplatinum(II) (approved for clinical use worldwide in 2003) is effective against colorectal tumors, which are nonsensitive to cisplatin. The consciousness that cisplatin readily reacts with DNA, and that this reaction is crucial in the antitumor activity, focused a great attention in the field of the interaction between metal complexes and biomolecules. Today, forty years after the discovery of the properties of cisplatin, there is no other metal, that is, better understood in its reactivity toward DNA than platinum. Moreover, despite the enormous amount of other metal complexes tested, cancer chemotherapy using metallopharmaceuticals is still largely dominated by platinum compounds [3]. The exploration of nonplatinum metal complexes for use as anticancer agents was initiated in attempts to find less toxic and more specific drugs. In this framework, some ruthenium and titanium complexes have offered the most encouraging results [4]. The imidazolium trans-[tetrachlorodimethylsulfoxideimidazoleruthenate(III)] (NAMI-A, [ImH][trans$\left.\mathrm{RuCl}_{4}(\mathrm{DMSO}) \mathrm{Im}\right], \mathrm{Im}=$ imidazole) failed the classical screens of putative anticancer agents, but prevented the development and growth of pulmonary metastases in solid tumors [5-8], and recently has successfully completed Phase I Clinical Trials [9]. The closely related compound, indazolium trans-[tetrachlorobis( $1 \mathrm{H}$-indazole)ruthenate(III)] $\left(\mathrm{KP} 1019,[\mathrm{IndH}]\left[\right.\right.$ trans- $\left.\mathrm{RuCl}_{4} \mathrm{Ind}_{2}\right]$, Ind $=$ indazole $)$ induces apoptosis in colorectal carcinoma cells and it is currently in Phase I Clinical Trials [10]. Two titanium compounds [11], namely titanocene dichloride $\left[\mathrm{TiCl}_{2} \mathrm{Cp}_{2}\right][12,13]$ and budotitane, a $\beta$-diketonate derivative, [cis-diethoxybis(1-phenylbutane-1,3-dionato)titanium (IV)] [14], reached Phase II and Phase I Clinical Trials in Germany, respectively. The general mechanism of action of these nonplatinum compounds is not completely under- stood yet, but many observations point out that DNA may not be the primary target of these classes of compounds $[15,16]$.

Characterization of DNA-adducts generally requires a combination of chemical and biological techniques to obtain structural information and to assess the extent and the nature of specific type of binding to DNA, in terms of dissociation constant, stoichiometry, and kinetic constant. Methods able to evaluate the presence of any interaction and, in some cases, to calculate the binding parameter can be classified as mixture- and separation-based methodology. The mexturebased type includes UV absorption and fluorescence [17], nuclear magnetic resonance (NMR, [18]), and Raman spectroscopy [19], mass spectrometry (MS, [20]), calorimetry [21], and surface plasma resonance [22]. The separationbased methods include dialysis, ultrafiltration, ultracentrifugation, chromatography (liquid chromatography and thinlayer chromatography), and electrophoresis (planar and capillary electrophoresis $[23,24])$. The last two separation methods are generally combined with sensitive detection techniques (hyphenated techniques), such as MS.

Among the physicochemical techniques, there has been a growing interest in electrochemical investigations. Compared to other methods, electrochemical techniques are characterized by simplicity and reliability and require small amounts of sample, thus offering advantages over biological and chemical assays. Since many small molecules exhibit redox activity, electrochemical method should provide a useful complement to the previously listed methods of investigation.

The electrochemical method is mainly based on the differences in the redox behavior of the nucleic acid-binding molecules in the absence and presence of DNA-including the shifts of the formal potential of the redox couple and the decrease of the peak current resulting from the dramatic decrease in the diffusion coefficient after association with DNA (solution electrochemical methods) (see [25] for a recent review).

On the other hand, since the discovery of the electrochemical activity of nucleic acids by Paleček at the end of the 1950s [26], also DNA has been on the focus of the electrochemical techniques. The binding of drugs to DNA has been described by means of the variation of the oxidation peak current of the electroactive nucleobases, such as guanine and adenine, in the presence of the interacting species.

According to a recent IUPAC document [27], a biosensor is defined as a specific type of chemical sensor comprising a biological recognition element and a physicochemical transducer. The biological element is capable of recognizing the presence, activity, or concentration of a specific analyte in solution. The recognition may be either a binding process (affinity ligand-based biosensor, when the recognition element is, e.g., an antibody, a DNA segment, or a cell receptor) or a biocatalytic reaction (enzyme-based biosensor). The interaction of the recognition element with a target analyte results in a measurable change in a given property. The transducer converts the change in solution property into a quantifiable signal. The mode of transduction may employ several techniques, including electrochemical, optical, and mass 
or heat measurements. In our case, the electrochemical DNA biosensor consists of a nucleic acid recognition layer, that is, immobilized over an electrochemical transducer [28]. The signal transducer monitors the change that has occurred as a consequence of the binding, converting this into an electronic signal [29]. Observing the pre- and postelectrochemical signals of DNA-drug interaction provides good evidence for the event. The reproducibility of the experiment is strictly related to the history of the electrode surface. In particular, the preparation of the electrode surface influences the final response. For this reason, the use of disposable, low-cost electrode characterized by high reproducibility overcomes the problem, as far as a new, fresh surface is used in each experiment. Various planar technologies are employed for developing solid-state sensors having the above-said characteristics [30]. Screen printing is especially suitable due to its simplicity, low-cost, high reproducibility, and efficiency in largescale production. This technology enables the deposition of a thick layer of conductive ink on inexpensive substrates and allows precise pattern control.

Although systematic research in this field started recently, several seminal review articles have already been focused on this topic [31-44].

The use of DNA-based biosensors is not limited to the study of interaction between drugs and DNA, but many other applications have been reported. On one hand, DNA- iosensors have been used to test water, food, soil, fish bile [45], and plant samples for the presence of mutagenic pollutants with binding affinities for the structure of DNA [33, 45-54]; on the other hand, DNA-based affinity biosensors have been used to detect specific oligonucleotide sequences in order to find the presence of genes (or mutant genes) associated with particular human diseases [55]. Both aspects are beyond the focus of this paper and will not be discussed further.

However, specific oligonucleotide sequences may be related to the protective cell mechanisms that act against anticancer drugs (drug resistance). One of the main obstacles in the use of metallodrugs in clinical treatment is the development of resistance. In the case of platinum drugs, many mechanisms have been proposed to explain resistance, suggesting that this phenomenon is multifactorial: decrease of intracellular drug accumulation, faster repair of DNA adducts, and increased activity of intracellular pathways of thiol production, in particular glutathione, metallothionein, and thioredoxin, known to be involved in the detoxification of metals. For these reasons, any information on DNAbinding modes, recognition, and repair of DNA damage may be helpful not only to understand the molecular basis of the repair mechanisms, but also to develop new classes of compounds with improved pharmacological properties $[56,57]$.

\section{DISCUSSION}

\subsection{Preparation of the screen-printed electrodes (SPEs)}

Screen printing is a technique conventionally used in the graphics industry, in the production of circuit boards, or in printing t-shirt designs. When inexpensive, easily mass pro-

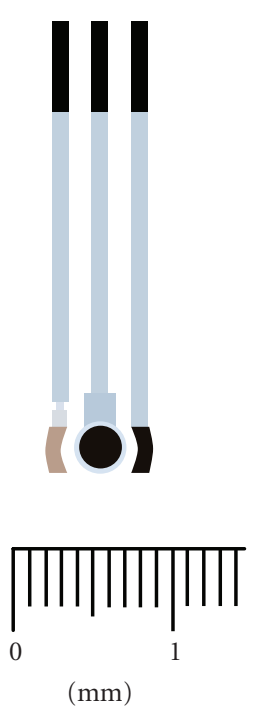

FIGURE 1: Scan of a screen-printed cell used as electrochemical transducer for the biosensors construction, containing the silver reference electrode (left), the graphite working (centre), and auxiliary electrodes (right).

duced, and, therefore, disposable electrodes for the development of electrochemical biosensors are required, screenprinting is a viable production method. Single use sensors assure avoidance of contamination between samples and constant sensitivity of the different printed sensors. A wide range of different inks (carbon or noble metals-based) and base materials (ceramics or plastic base materials) can be combined to produce electrode systems to suit specific applications.

The planar SPEs used in our laboratories have a threeelectrode configuration (Figure 1). They are printed by using inks consisting in finely divided particles of different materials in a blend of thermoplastic resins (silver ink for the reference electrode, graphite ink for working and counter electrodes, while titanium dioxide ink was used for insulating the electrodes).

The sensors were produced in sheets of 80 electrodes. To facilitate handling, the screen-printed electrochemical cells were stuck on a rigid polycarbonate-based support. Each (disposable) electrode can be easily cut by scissors and fits a standard electrical connector $[30,58,59]$.

\subsection{Preparation of the biosensor}

As already mentioned in the Introduction, a biosensor is defined as an analytical device, which is capable of providing quantitative or semiquantitative analytical information using a biological recognition element either integrated within or intimately associated with a physicochemical transducer [27]. In our case, the transducer is the SPE while the oxidation peak of guanines is used as the transduction signal for recognize DNA interactions.

The preparation and the following measurement of the interaction at the DNA-modified SPEs include four steps [50] 
(1) Electrode activation: a (mild) surface conditioning step is necessary to oxidize the graphite impurities and to obtain a more hydrophilic surface to favor DNA immobilization $(+1.6 \mathrm{~V}$ versus $\mathrm{Ag}$-pseudoreference for 120 seconds and $+1.8 \mathrm{~V}$ for 60 seconds in $0.25 \mathrm{M}$ acetate buffer, containing $10 \mathrm{mM} \mathrm{KCl}, \mathrm{pH} 4.75$, under stirred conditions).

(2) DNA immobilization: in this step DNA is electrochemically accumulated and adsorbed onto the electrode surface by applying a positive potential able to attract negative charged groups of DNA (activated SPE is dipped in a solution of 50 ppm calf thymus ds-DNA in $0.25 \mathrm{M}$ acetate buffer with $10 \mathrm{mM} \mathrm{KCl}$, applying a potential of $+0.5 \mathrm{~V}$ versus Ag-SPE for 5 minutes, under stirred conditions).

(3) Blank or sample interaction: in this step, the response of the guanine before (reference signal) or after interaction is evaluated (the DNA-modified SPE is dipped for 2 minutes in a solution containing the interacting molecule dissolved in a suitable buffer/saline solution or in the same buffer saline solution without any analyte, to obtain the reference).

(4) Measurement: a square wave voltammetric (SWV) scan is carried out to evaluate the oxidation of guanine residues on the electrode surface (the height of the guanine peak at $+0.95 \mathrm{~V}$ versus $\mathrm{Ag}-\mathrm{SPE}$ was measured in $0.25 \mathrm{M}$ acetate buffer, containing $10 \mathrm{mM} \mathrm{KCl}$ ).

The four-step protocol is the result of a series of experiments aimed to optimize the final response, in terms of peak height and reproducibility of the signal $[50,60]$. The results showed an increase of the sensitivity increasing DNA concentration (until a saturation phenomenon occurred) and the immobilization time (similar results were obtained by other authors. See [61]). The $50 \mathrm{ppm}$ ds-DNA concentration and an immobilization time of 5 minutes (step 2) were chosen as the best compromise for further experiments.

DNA biosensor performances were strongly influenced by the physical properties of DNA (i.e., purity, average chain length, presence of ss-DNA) [48]. Moreover, the solution where the final measurement is performed influences the signal aspect: the acetate buffer gives the best results $[48,50]$, and this choice was reported also by other authors [62].

We usually estimate the DNA modification due to the interaction with the analyte with the value of the percentage of signal decrease $(S \%)$. This value is the ratio of the guanine peak height after the interaction of the DNA adsorbed onto the SPE with the analyte $\left(S_{\text {sample }}\right)$ and the guanine peak height of the DNA in the buffer solution without $\operatorname{drug}\left(S_{\text {blank }}\right), S \%=\left(S_{\text {sample }} / S_{\text {blank }}\right) \times 100$. A typical voltammogram is shown in Figure 2.

It must be noted that the two curves of Figure 2 have been obtained from two different SPEs. In fact, only one SWV scan is allowed on each biosensor. If a second SWV is performed, no peak can be observed because of the complete oxidation of the guanine of the immobilized DNA [48]. For this reason, the final $S \%$ values are expressed as a mean of (at least) three independent measurements. With this procedure, the "memory effect" between one sample and another is avoided.

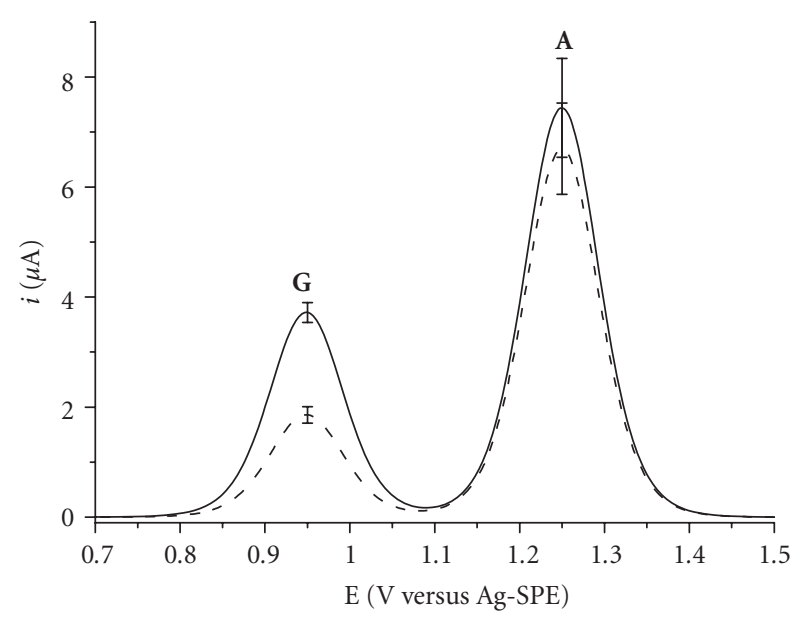

Figure 2: Redox behavior of guanine $(\mathrm{G},+0.95 \mathrm{~V}$ versus Ag-SPE) and adenine $(\mathrm{A},+1.25 \mathrm{~V}$ versus Ag-SPE) bases after an SWV scan carried out with graphite SPE (a baseline correction on the original signals was performed). Note that the signal of DNA alone (solid line) and the decrease of the DNA peaks after the interaction with a general compound able to interact with DNA (dashed line).

The phenomenon referred to as "electrode fouling," which is one of the main drawbacks of the electrochemical sensors, is overcome and no calibration is required. Furthermore, the reproducibility of the guanine peak height, calculated over three or more scans on different electrodes is very high, and the standard deviation was estimated to be less than $10 \%$.

It is also possible to study the adenine oxidation peak, but in this case less reproducible signals are obtained (see error bars in Figure 2) [54]. Moreover, this peak is sometimes obscured by the solvent discharge.

Covalent binding with one or both grooves of the double helix, hydrogen and/or van der Waals bonds and intercalation of planar condensed aromatic ring systems between adjacent base pairs ( $\pi$-stacking) are the perturbations that the electrochemical DNA biosensor can detect [63].

\subsection{Platinum complexes $[64,65]$}

Cisplatin, 1 (Figure 3), is administered intravenously for clinical use. In the extracellular environment, the platinum compound experiences high chloride concentration $(\sim 100 \mathrm{mM})$ and does not undergo appreciable hydrolysis. When cisplatin passes the cell membrane, the reduced intracellular chloride concentration $(\sim 5-10 \mathrm{mM})$ allows the chloro ligands to be replaced in a stepwise manner by water molecules to form cis- $\left[\mathrm{Pt}\left(\mathrm{H}_{2} \mathrm{O}\right)\left(\mathrm{NH}_{3}\right)_{2} \mathrm{Cl}\right]^{+}$and cis$\left[\mathrm{Pt}\left(\mathrm{H}_{2} \mathrm{O}\right)_{2}\left(\mathrm{NH}_{3}\right)_{2}\right]^{2+}[66]$. It is generally accepted that these two ions are much more reactive than cisplatin and, therefore, react with $\mathrm{N}$-donor ligands, such as DNA nucleobases (the preferred target on DNA is recognized as the guanines having the highest electron density of all four nucleobases), leading to the bending of the DNA structure by 35-40 $[67-$ 69]. This key reaction is responsible for the anticancer effect of cisplatin which is able to induce apoptosis/necrosis of the cancer cell [70]. Carboplatin, 2, undergoes much slower 


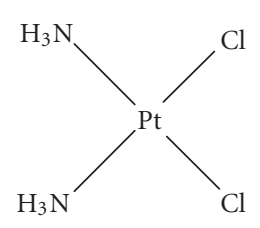

Cisplatin, 1

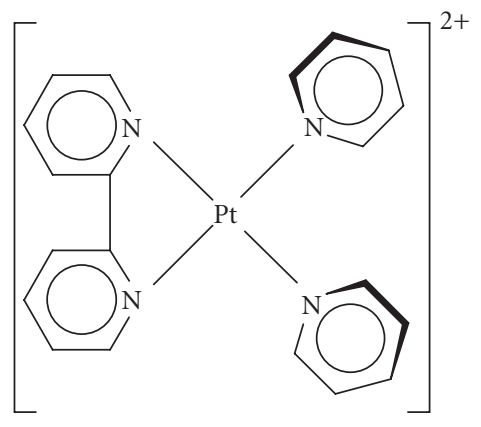

$\left[\operatorname{Pt}(\mathrm{bpy})(\mathrm{py})_{2}\right]^{2+}, 3$

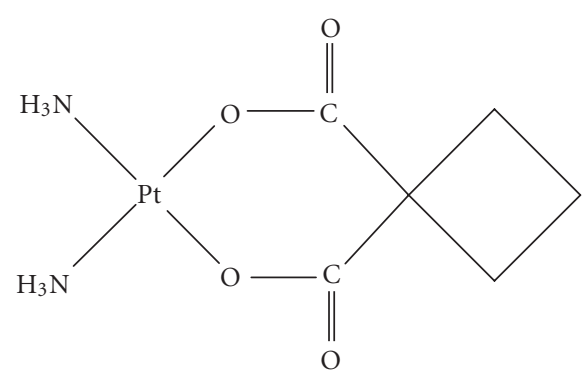

Carboplatin, 2

Figure 3: Sketch of the Pt(II) complexes investigated.

hydrolysis than cisplatin. Since the DNA reactions are primarily limited by the hydrolytic pathways, the reaction between carboplatin and DNA is extremely slow under physiological conditions. For example, the half life of carboplatin reaction with DNA is estimated to be several days [71].

The behavior of these two complexes was compared with that of $\left[\mathrm{Pt}(\mathrm{bpy})(\mathrm{py})_{2}\right]\left[\mathrm{PF}_{6}\right]_{2}, 3$ (bpy = bipyridyl, py = pyridine). This complex lacks appropriate leaving groups, so that 3 is devoid of any alkylating properties, but is able to intercalate DNA [72].

Figure 4 shows the trend of $S \%$ values resulting from the interaction between DNA biosensor and a $0.1 \mathrm{mM}$ solution of 1 in $5 \mathrm{mM}$ (intracellular conditions) and $100 \mathrm{mM}$ (extracellular conditions) $\mathrm{NaCl}$, respectively. As expected, the behavior of 1 strictly depends on the concentration of the $\mathrm{NaCl}$ and on the aging time of the solution: high concentrations of chlorides inhibit the aquation of cisplatin and, hence, its interaction with DNA.

As far as $\mathbf{1}$ becomes, after hydrolysis, doubly positive charged species, we have checked whether a simple longrange electrostatic interaction in lieu of an effective coordination to DNA is able to affect the oxidation signal of guanine. For this purpose, we have tested the interaction between the biosensor and solutions containing divalent cations $\mathrm{Zn}$ (II) and $\mathrm{Cu}(\mathrm{II})$. For both solutions, no variation in the guanine signal was observed $(S \%=100 \%)$.

Figure 5 shows the $S \%$ values resulting from increasing concentrations of metal complexes $1-3$ in $0.25 \mathrm{M}$ phosphate buffer $(\mathrm{PB}, \mathrm{pH}=7.4)$, containing $5 \mathrm{mM} \mathrm{NaCl}$ (intracellular conditions).
The interaction increases in a dose-dependent manner, and is stronger for $\mathbf{1}$ and softer for $\mathbf{2}$. Compound $\mathbf{3}$ shows an initial strong interaction, overimposable to that of 1 , but a minor one at higher concentrations, probably because of the saturation of the intercalating sites on DNA.

Figure 6 compares the behavior of the three metal complexes in identical experimental conditions (in particular at the same concentration) when the solution aging time is varied. As expected, a stronger effect of solution aging time on $S \%$ is observed for $\mathbf{1}$, while, in the case of $\mathbf{3}$, hydrolysis is not required. In fact, this complex does not need to dissociate any ancillary ligand to exert its activity.

Compounds 1 and 2 produce the same electrophilic agent upon hydrolysis, namely $\left[\mathrm{Pt}\left(\mathrm{H}_{2} \mathrm{O}\right)_{2}\left(\mathrm{NH}_{3}\right)_{2}\right]^{2+}$, nevertheless, Figures 5 and 6 reveal that the interaction of carboplatin is much lower than that of cisplatin because of the different rate of hydrolysis $\left(t_{1 / 2}\right.$ in chloride-free phosphate at $37^{\circ} \mathrm{C}$ is about 450 hours for 2 [71] compared with 2 hours for cisplatin [73]).

In the case of 2 , the rate of hydrolysis, and hence the interaction with DNA, is increased in the presence of chlorides. In fact, an exchange between the 1,1-cyclobutanedicarboxylato ligand and chlorides in solution is able to transform 2 in $\mathbf{1}$ [74] that, in turn, undergoes quick activation by aquation. This effect is negligible in the presence of weaker Lewis bases, for instance perchlorates (Figure 7). The exchange reaction is time-dependent as observed in both in 2 and in its malonato-analogue (cis-diamminomalonatoplatinum, $\left[\mathrm{Pt}\left(\mathrm{NH}_{3}\right)_{2}\right.$ (malonato) $\left.], 4\right)$, and increases with $\left[\mathrm{Cl}^{-}\right]$(Figure 8 ). 


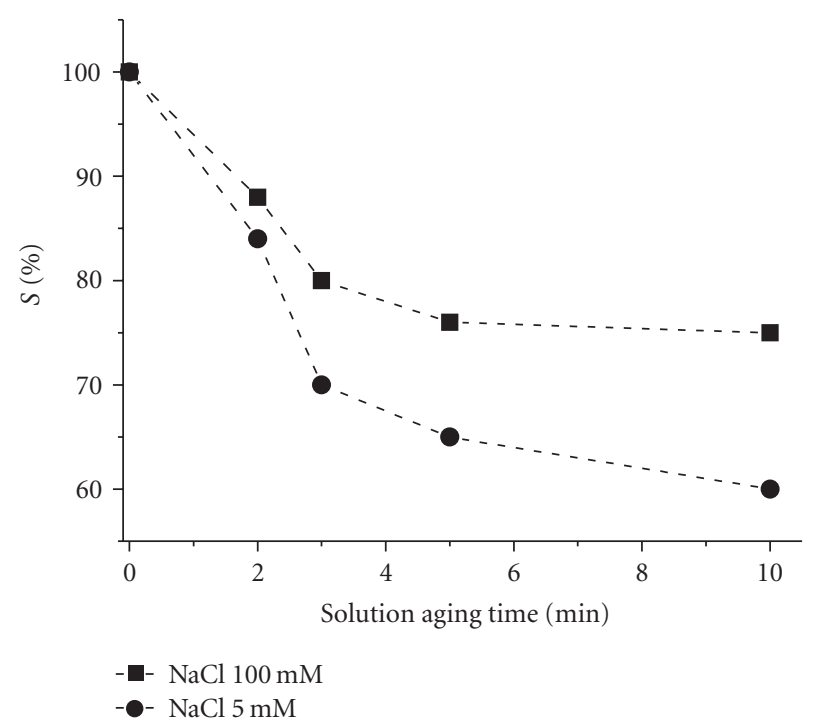

FIGURE 4: $S \%$ versus solution aging time for $0.1 \mathrm{mM}$ solution of 1 in unbuffered ( $\mathrm{pH}=7.4) 5 \mathrm{mM} \mathrm{NaCl}$ (circles), and $100 \mathrm{mM} \mathrm{NaCl}$ (squares) solutions, respectively.

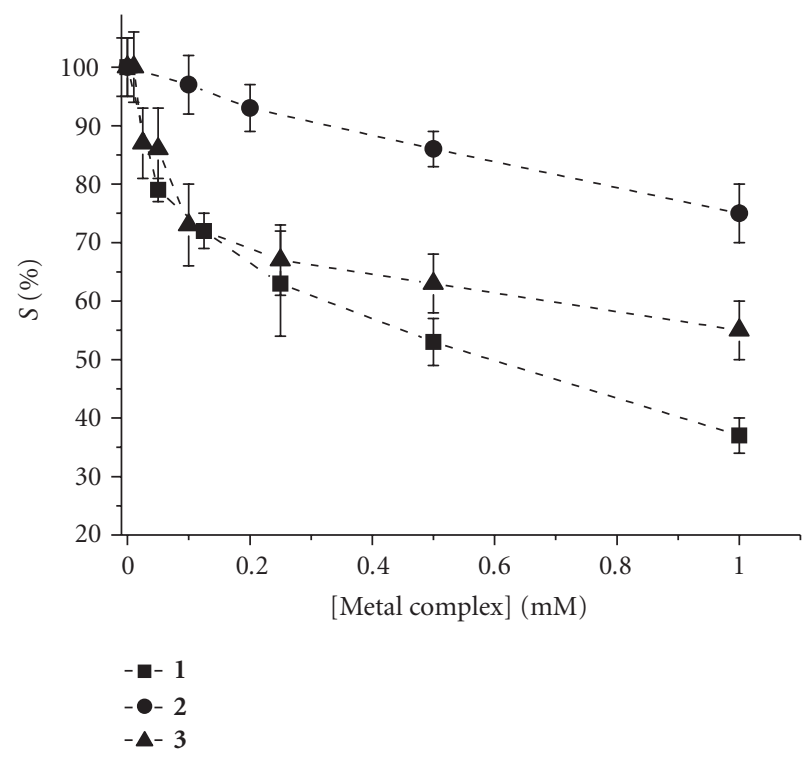

FIGURE 5: $S \%$ resulting from increasing concentrations of metal complexes in $0.25 \mathrm{M} \mathrm{PB}(\mathrm{pH}=7.4)$ and $5 \mathrm{mM} \mathrm{NaCl}$ (interaction time $=2$ minutes).

The biosensor may also be used to differentiate the intercalating from the covalent interactions. In fact, by using the same experimental procedures previously described, it is possible to adsorb single-stranded DNA onto the SPE [48]. Similar concentrations of compound $\mathbf{3}$ gave lower $S \%$ values (i.e., higher interaction) on the ds-DNA- versus the ss-DNAbased sensor ( $S \%=65 \pm 3$ versus $92 \pm 3$, resp.), enforcing the experimental data that identify this complex as an intercalator in lieu of a coordinating agent.

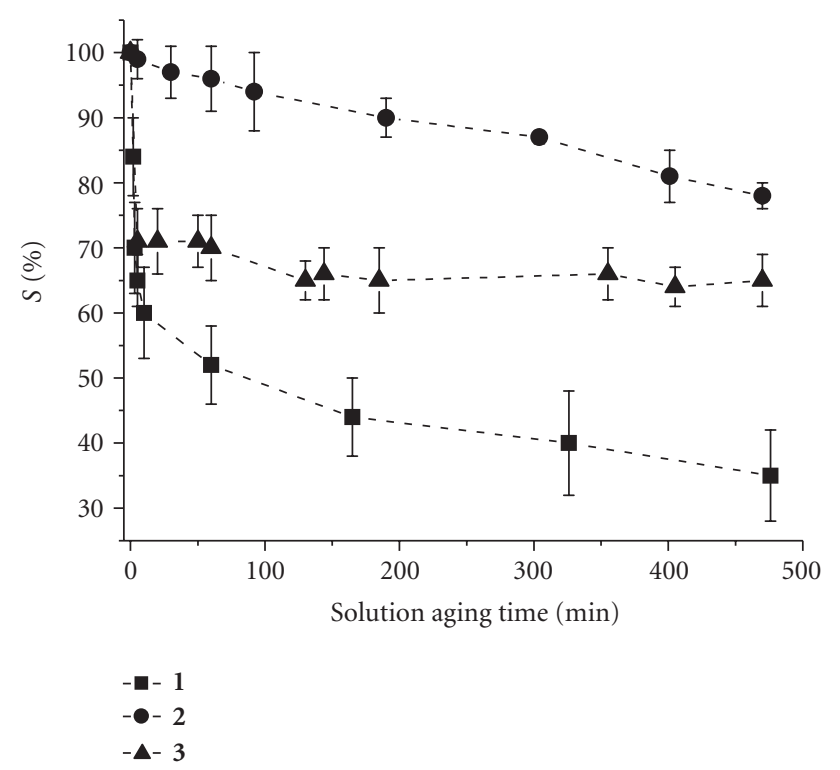

FIGURE 6: $S \%$ versus solution aging time for $0.5 \mathrm{mM}$ solution of the metal complexes $1-3$ in $0.25 \mathrm{M} \mathrm{PB}(\mathrm{pH}=7.4)$ and $5 \mathrm{mM} \mathrm{NaCl}$.

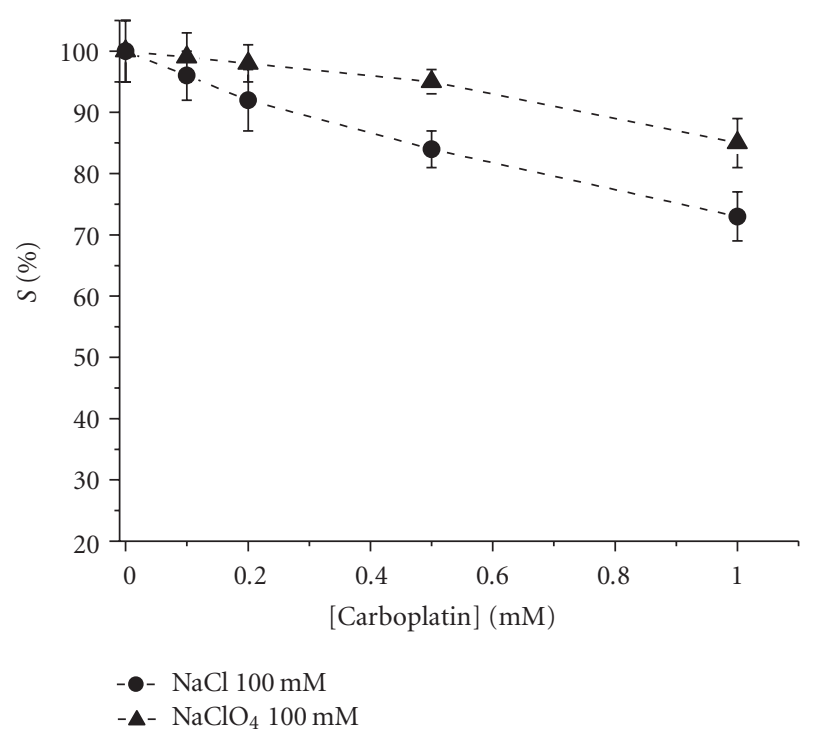

FIGURE 7: S\% obtained with different concentrations of carboplatin in $100 \mathrm{mM} \mathrm{NaCl}$ or $100 \mathrm{mM} \mathrm{NaClO}_{4}$, respectively.

\subsection{Ruthenium complexes: NAMI-A}

The complex NAMI-A, $\left(\mathrm{H}_{2} \mathrm{Im}\right)\left[\right.$ trans- $\mathrm{Ru}(\mathrm{III}) \mathrm{Cl}_{4}(\mathrm{DMSO})$ (Im)], is a pseudo-octahedral complex with four equatorial chloride ligands and the heterocyclic bases and DMSO as axial ligands (Figure 9).

The complex loses its chloride ligands and transforms into the corresponding, more reactive, aquated species [4] able to bind irreversibly to DNA, albeit this binding is weaker 


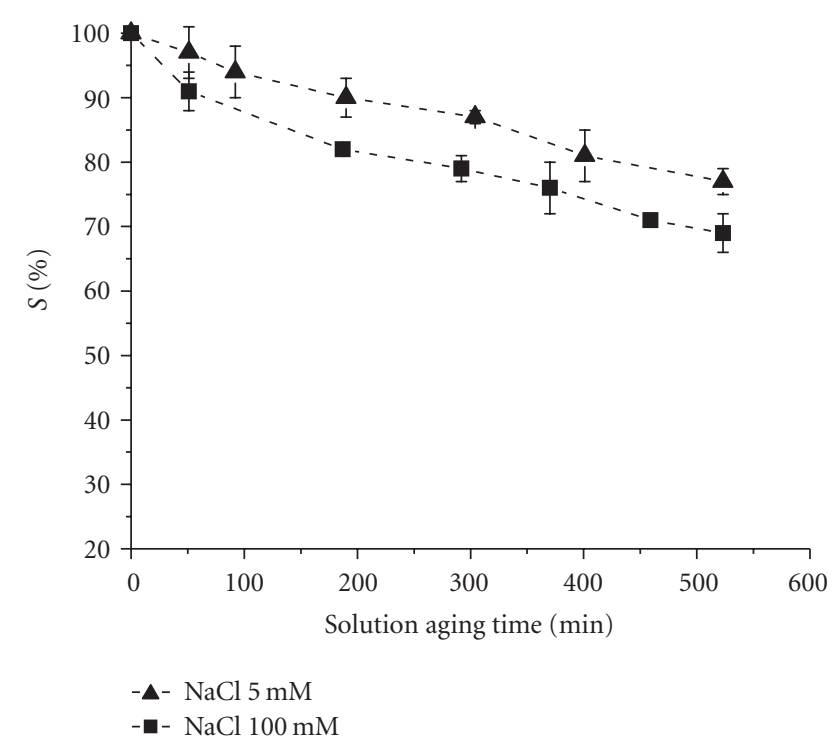

FIGURE 8: S\% versus solution aging time for $0.5 \mathrm{mM}$ solution of 4 in 5 or $100 \mathrm{mM} \mathrm{NaCl}$, respectively, (previously unpublished data).
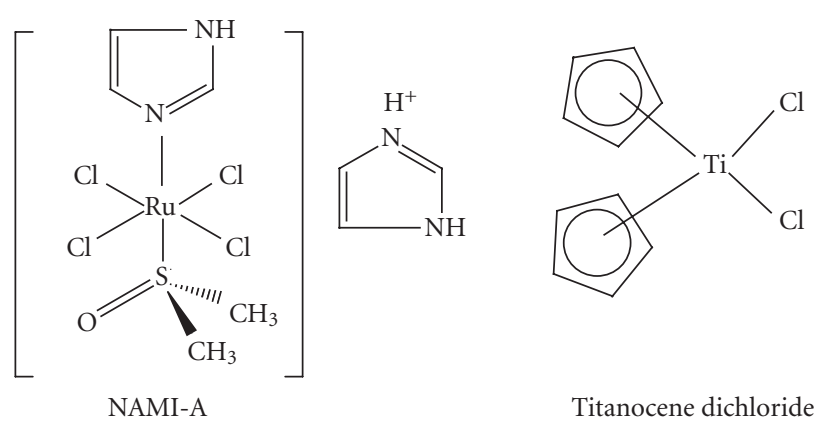

FIGURE 9: Sketch of the non-Pt(II) complexes investigated.

than for similar platinum complexes [75]. In fact, Gallori et al. showed that NAMI-A interacts with DNA at concentrations significantly higher than those at which cisplatin produces similar effects [76]. On the other hand, tight binding of NAMI-A to proteins has been described $[64,77,78]$ and it is likely to conceive that the mechanism underlying the antimetastatic activities of NAMI-A does not involve DNA binding as the most significant process, but, perhaps the inhibition of the matrix metallo-proteinases MMP-2 and MMP-9 [8].

Also in the case of NAMI-A, S\% value decreases as concentration increases (Figure 9), but the concentration of the supporting electrolyte plays minor roles (Figures 9 and 10). In fact, $\mathrm{NaCl}$, that should exert mass effect, and $\mathrm{NaClO}_{4}$, that produces the noncoordinating perchlorate anion, gave similar results (Figure 9) [64]. Indeed, it is known in literature that chlorides have a minor effect over NAMI-A aquation [79]. NAMI-A shows higher S\% values in comparison with 1, especially at low chloride concentration. These experimental data further reinforce the hypothesis that DNA is not the preferential targets of NAMI-A.

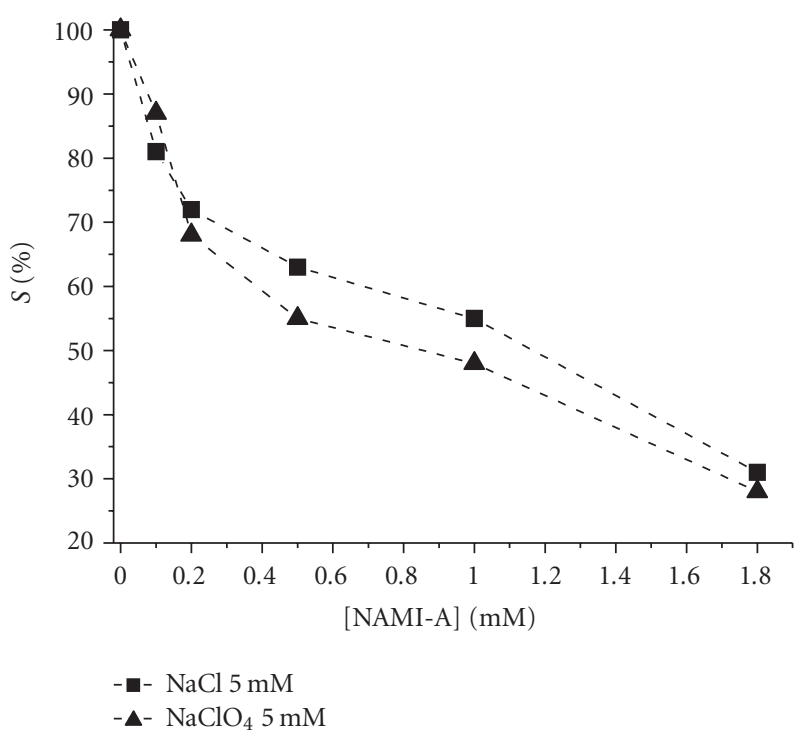

Figure 10: $S \%$ versus [NAMI-A] in $5 \mathrm{mM} \mathrm{NaCl}$ (squares) and $5 \mathrm{mM} \mathrm{NaClO}_{4}$ (triangles) solutions, respectively.

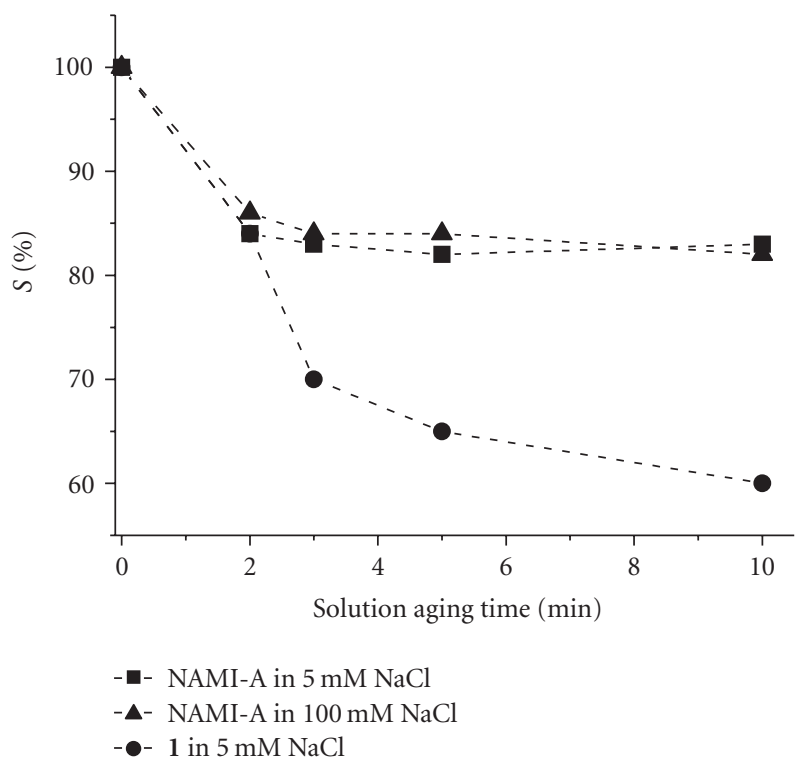

FIGURE 11: S\% versus solution aging time for $0.1 \mathrm{mM}$ solution of NAMI-A in $5 \mathrm{mM} \mathrm{NaCl}$ (squares) and $100 \mathrm{mM} \mathrm{NaCl}$ (triangles) solutions, respectively, compared to the trend of the same concentration of 1 in $5 \mathrm{mM} \mathrm{NaCl}$ (circles).

\subsection{Titanium complexes}

Unlike the very well-studied platinum complexes, interactions of Ti complexes with DNA are poorly understood. It seems that titanocene dichloride $\mathrm{TiCp}_{2} \mathrm{Cl}_{2}$ (Figure 11) is able to interact with transferrin, the protein associated with iron transport. In this form, titanium active species could cross the cell membrane, but the nature of the actual cytotoxic species remains unknown [15].

In literature, there are conflicting results about whether titanocene dichloride binds DNA or not. Some reports have 
suggested that $\mathrm{TiCp}_{2} \mathrm{Cl}_{2}$ does not bind nucleotides and oligonucleotides at physiological $\mathrm{pH}$ [80-82], but there is experimental evidences of titanium being accumulated in the cellular nucleic acid-rich regions, particularly in the chromatin [83]. Recently, it has been shown that $\mathrm{TiCp}_{2} \mathrm{Cl}_{2}$ interacts weakly with nucleotides at neutral $\mathrm{pH}$ through the phosphoesters most probably as bare Ti(IV) species [84].

These conflicting results about titanocene dichloride binds DNA prompted us to test if the biosensor were able to give some information about the degree of interaction.

Figures 12 and 13 show, unequivocally, that $\mathrm{TiCp}_{2} \mathrm{Cl}_{2}$ has a lower degree of interaction with DNA biosensor than cisplatin [65]. The trend of $S \%$ with solution aging time is almost constant. These two points fit with the literature data showing that the hydrolysis of $\mathrm{TiCp}_{2} \mathrm{Cl}_{2}$ proceeds much faster than cisplatin: the half-life of the first aquation of chloride ligand is too fast to be measured and the second aquation step has a $t_{1 / 2} \approx 50$ minutes [80]. Therefore, we expect that both the active species $\left[\operatorname{TiCp}_{2}\left(\mathrm{H}_{2} \mathrm{O}\right) \mathrm{Cl}\right]^{+}$and $\left[\mathrm{TiCp}_{2}\left(\mathrm{H}_{2} \mathrm{O}\right)_{2}\right]^{2+}$ are present in solution just at the beginning of the experiment. If we accept that the DNA binding occurs at the phosphate groups level, it is evident that an ionic interaction between Ti cation and external phosphate backbone produces a minor effect on the oxidation of $\mathrm{G}$ with respect to the direct coordination of N7.

\section{CONCLUDING REMARKS}

In the field of environmental sciences it has been demonstrated the good relationship between genotoxicity of a sample (measured by specific assays like Toxalert) and the presence of substances with high affinity for DNA (measured by the DNA biosensor) $[48,50,51]$, but the use of biosensors in pharmacokinetic studies deserves some caution.

It is generally accepted that a direct relationship between cytotoxicity and DNA-bound Pt exists [85-87], but there are also many factors that hamper the DNA platination. The DNA biosensors do not give an "absolute" measure of the genotoxic power of a potential drug as it uses DNA free of histones, not organized in superior structures, and nuclear and cellular membranes are missing. Furthermore, in a cell-free system, the cellular thiols (glutathione and metallothioneins) able to intercept the platinum complexes are not present and other repair mechanisms are missing.

Moreover, the ratio between metal drug and DNA is far from real pharmacological conditions. In fact, in the case of Pt drugs, it has been measured that cytotoxicity occurs when there are around 2-10 nmoles of Pt/g DNA [88]. Our determinations revealed that about $3 \times 10^{-9} \mathrm{~g}$ of DNA coated the biosensor $[65,89]$. This means that the ratio between metal complex and immobilized DNA is incredibly high and in these conditions a large number of compounds could interact with guanine, even without being active antitumor drugs.

However, this procedure can be very useful for a rapid screening of the samples and may be of interest in studying (i) the possible reaction of the metal complex in solution and hence the formation of DNA-active or inactive species by reaction with water or other molecules acting as ligand (i.e., chlorides), and (ii) the strength of perturbation caused di-

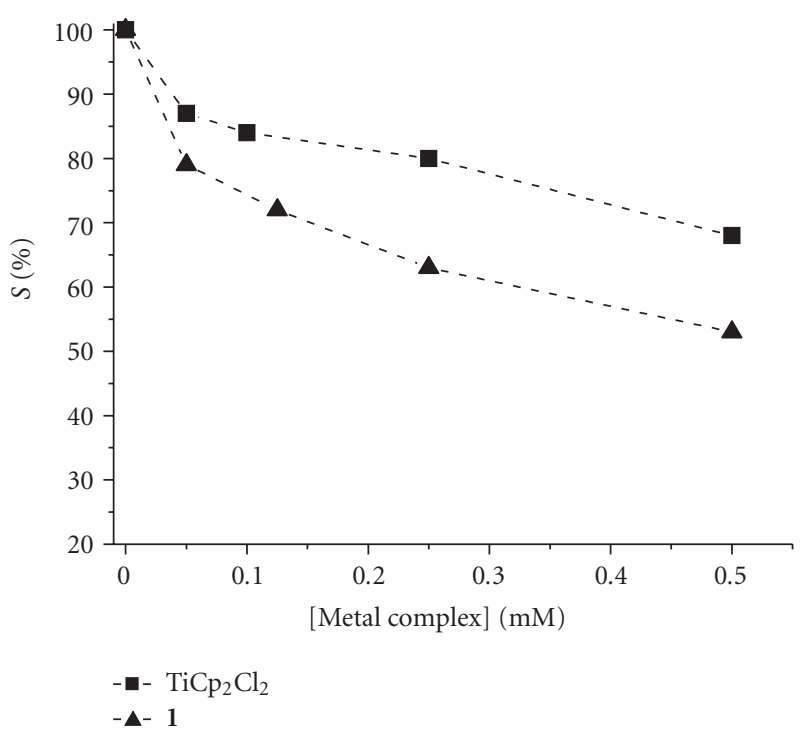

Figure 12: $S \%$ versus [metal complex] in $0.25 \mathrm{M} \mathrm{PB} / 5 \mathrm{mM} \mathrm{NaCl}$ solutions of $\mathrm{TiCp}_{2} \mathrm{Cl}_{2}$ and $\mathbf{1}$, respectively.

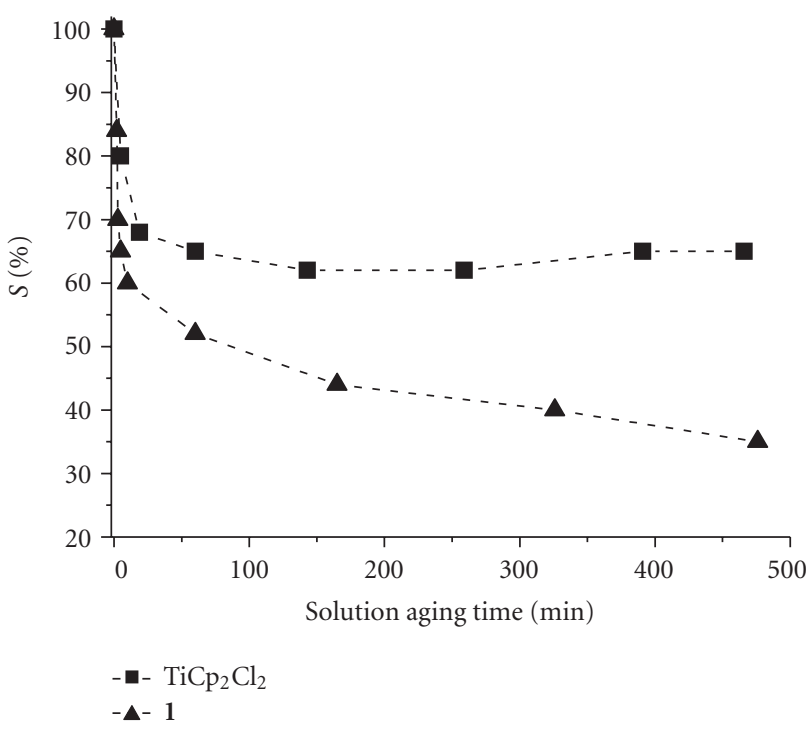

FIgURE 13: $S \%$ versus solution aging time for $0.5 \mathrm{mM}$ solution of $\mathrm{TiCp}_{2} \mathrm{Cl}_{2}$ in $0.25 \mathrm{M} \mathrm{PB} / 5 \mathrm{mM} \mathrm{NaCl}$, compared to the trend of the same concentration of $\mathbf{1}$.

rectly or through the DNA chain by such metallodrugs on the electron density of N7-G, that is, the real observable in such a measurements.

For the above reasons, the DNA biosensor could give useful and quick information and could be integrated in a panel of tests in order to quickly evaluate and quantifies the affinity of low-weight molecules with DNA.

\section{ACKNOWLEDGMENTS}

Useful discussions were carried out with colleagues within the framework of the European Cooperation COST D39 
(Metallo-Drug Design and Action) and COST B16 (Multidrug resistance reversal) actions. The contributions of the many talented students and coworkers who have contributed to the work described in this review are acknowledged. This paper is based on a lecture given by the first author at the 9th International Symposium on Applied Bioinorganic Chemistry (ISABC) held in Naples, Italy, on December 4th, 2006.

\section{REFERENCES}

[1] G. Bischoff and S. Hoffmann, "DNA-binding of drugs used in medicinal therapies," Current Medicinal Chemistry, vol. 9, no. 3, pp. 321-348, 2002.

[2] L. L. Brunton, J. S. Lazo, and K. L. Parker, Eds., Goodman \& Gilman's the Pharmacological Basis of Therapeutics, McGrawHill, New York, NY, USA, 11th edition, 2006.

[3] B. Lippert, Ed., Cisplatin: Chemistry and Biochemistry of a Leading Anticancer Drug, Wiley-VCH, New York, NY, USA, 1999.

[4] M. J. Clarke, F. Zhu, and D. R. Frasca, "Non-platinum chemotherapeutic metallopharmaceuticals," Chemical Reviews, vol. 99, no. 9, pp. 2511-2533, 1999.

[5] G. Sava, I. Capozzi, K. Clerici, G. Gagliardi, E. Alessio, and G. Mestroni, "Pharmacological control of lung metastases of solid tumours by a novel ruthenium complex," Clinical and Experimental Metastasis, vol. 16, no. 4, pp. 371-379, 1998.

[6] G. Sava, A. Bergamo, S. Zorzet, et al., "Influence of chemical stability on the activity of the antimetastasis ruthenium compound NAMI-A," European Journal of Cancer, vol. 38, no. 3, pp. 427-435, 2002.

[7] A. Bergamo, R. Gagliardi, V. Scarcia, et al., "In vitro cell cycle arrest, in vivo action on solid metastasizing tumors, and host toxicity of the antimetastatic drug NAMI-A and cisplatin," Journal of Pharmacology and Experimental Therapeutics, vol. 289, no. 1, pp. 559-564, 1999.

[8] G. Sava, S. Zorzet, C. Turrin, et al., "Dual action of NAMI-A in inhibition of solid tumor metastasis: selective targeting of metastatic cells and binding to collagen," Clinical Cancer Research, vol. 9, no. 5, pp. 1898-1905, 2003.

[9] J. M. Rademaker-Lakhai, D. van den Bongard, D. Pluim, J. H. Beijnen, and J. H. M. Schellens, "A phase I and pharmacological study with imidazolium-trans-DMSO-imidazoletetrachlororuthenate, a novel ruthenium anticancer agent," Clinical Cancer Research, vol. 10, no. 11, pp. 3717-3727, 2004.

[10] S. Kapitza, M. Pongratz, M. A. Jakupec, et al., "Heterocyclic complexes of ruthenium(III) induce apoptosis in colorectal carcinoma cells," Journal of Cancer Research and Clinical Oncology, vol. 131, no. 2, pp. 101-110, 2005.

[11] F. Caruso and M. Rossi, "Antitumor titanium compounds," Mini-Reviews in Medicinal Chemistry, vol. 4, no. 1, pp. 49-60, 2004.

[12] G. Lümmen, H. Sperling, H. Luboldt, T. Otto, and H. Rübben, "Phase II trial of titanocene dichloride in advanced renal-cell carcinoma," Cancer Chemotherapy and Pharmacology, vol. 42, no. 5, pp. 415-417, 1998.

[13] N. Kröger, U. R. Kleeberg, K. Mross, L. Edler, and D. K. Hossfeld, "Phase II clinical trial of titanocene dichloride in patients with metastatic breast cancer," Onkologie, vol. 23, no. 1, pp. 60-62, 2000.

[14] T. Schilling, K. B. Keppler, M. E. Heim, et al., "Clinical phase I and pharmacokinetic trial of the new titanium complex budotitane," Investigational New Drugs, vol. 13, no. 4, pp. 327332, 1995.
[15] M. Guo, H. Sun, H. J. McArdle, L. Gambling, and P. J. Sadler, " $\mathrm{Ti}^{\mathrm{IV}}$ uptake and release by human serum transferrin and recognition of $\mathrm{Ti}^{\mathrm{IV}}$-transferrin by cancer cells: understanding the mechanism of action of the anticancer drug titanocene dichloride," Biochemistry, vol. 39, no. 33, pp. 10023-10033, 2000.

[16] E. Alessio, G. Mestroni, A. Bergamo, and G. Sava, "Ruthenium anticancer drugs," in Metal Complexes in Tumor Diagnosis and as Anticancer Agents, A. Sigel and H. Sigel, Eds., vol. 42 of Metal Ions in Biological Systems, chapter 10, pp. 323-351, Marcel Dekker, New York, NY, USA, 2004.

[17] T. C. Jenkins, "Optical absorbance and fluorescence techniques for measuring DNA drug interactions," in Drug DNA Interaction Protocols, K. R. Fox, Ed., vol. 90 of Methods in Molecular Biology, pp. 195-218, Humana Press, Totowa, NJ, USA, 1997.

[18] M. S. Searle, "NMR studies of drug-DNA interactions," Progress in Nuclear Magnetic Resonance Spectroscopy, vol. 25, no. 5, pp. 403-480, 1993.

[19] J. M. Benevides, S. A. Overman, and G. J. Thomas Jr., "Raman, polarized Raman and ultraviolet resonance Raman spectroscopy of nucleic acids and their complexes," Journal of Raman Spectroscopy, vol. 36, no. 4, pp. 279-299, 2005.

[20] A. Di Tullio, S. Reale, and F. De Angelis, "Molecular recognition by mass spectrometry," Journal of Mass Spectrometry, vol. 40, no. 7, pp. 845-865, 2005.

[21] H. P. Hopkins, "Calorimetric techniques for studying drugDNA interactions," in Drug DNA Interaction Protocols, K. R. Fox, Ed., vol. 90 of Methods in Molecular Biology, pp. 259-268, Humana Press, Totowa, NJ, USA, 1997.

[22] L.-P. Lin, L.-S. Huang, C.-W. Lin, et al., "Determination of binding constant of DNA-binding drug to target DNA by surface plasmon resonance biosensor technology," Current Drug Targets: Immune, Endocrine \& Metabolic Disorders, vol. 5, no. 1, pp. 61-72, 2005.

[23] C. Schou and N. H. H. Heegaard, "Recent applications of affinity interactions in capillary electrophoresis," Electrophoresis, vol. 27, no. 1, pp. 44-59, 2006.

[24] J. Zavaleta, D. Chinchilla, A. Brown, et al., "Recent developments in affinity capillary electrophoresis: a review," Current Analytical Chemistry, vol. 2, no. 1, pp. 35-42, 2006.

[25] S. Rauf, J. J. Gooding, K. Akhtar, et al., "Electrochemical approach of anticancer drugs-DNA interaction," Journal of Pharmaceutical and Biomedical Analysis, vol. 37, no. 2, pp. 205-217, 2005.

[26] E. Paleček, "Oscillographic polarography of highly polymerized deoxyribonucleic acid," Nature, vol. 188, no. 4751, pp. 656-657, 1960.

[27] D. R. Thévenot, K. Toth, R. A. Durst, and G. S. Wilson, "Electrochemical biosensors: recommended definitions and classification," Biosensors and Bioelectronics, vol. 16, no. 1-2, pp. 121-131, 2001.

[28] F. Lucarelli, G. Marrazza, A. P. F. Turner, and M. Mascini, "Carbon and gold electrodes as electrochemical transducers for DNA hybridisation sensors," Biosensors and Bioelectronics, vol. 19, no. 6, pp. 515-530, 2004.

[29] J. J. Gooding, "Electrochemical DNA hybridization biosensors," Electroanalysis, vol. 14, no. 17, pp. 1149-1156, 2002.

[30] S. Laschi and M. Mascini, "Planar electrochemical sensors for biomedical applications," Medical Engineering and Physics, vol. 28, no. 10, pp. 934-943, 2006.

[31] S. Palanti, G. Marrazza, and M. Mascini, "Electrochemical DNA probes," Analytical Letters, vol. 29, no. 13, pp. 2309-2331, 1996. 
[32] E. Paleček, "From polarography of DNA to microanalysis with nucleic acid-modified electrodes," Electroanalysis, vol. 8, no. 1, pp. 7-14, 1996.

[33] J. Wang, G. Rivas, X. Cai, et al., "DNA electrochemical biosensors for environmental monitoring. a review," Analytica Chimica Acta, vol. 347, no. 1-2, pp. 1-8, 1997.

[34] J. Zhai, H. Cui, and R. Yang, "DNA based biosensors," Biotechnology Advances, vol. 15, no. 1, pp. 43-58, 1997.

[35] E. Paleček, M. Fojta, M. Tomschik, and J. Wang, "Electrochemical biosensors for DNA hybridization and DNA damage," Biosensors and Bioelectronics, vol. 13, no. 6, pp. 621-628, 1998.

[36] E. Paleček, "Past, present and future of nucleic acids electrochemistry," Talanta, vol. 56, no. 5, pp. 809-819, 2002.

[37] A. Erdem and M. Ozsoz, "Electrochemical DNA biosensors based on DNA-drug interactions," Electroanalysis, vol. 14, no. 14, pp. 965-974, 2002.

[38] J. Wang, "Real-time electrochemical monitoring: toward green analytical chemistry," Accounts of Chemical Research, vol. 35, no. 9, pp. 811-816, 2002.

[39] M. Dequaire and A. Heller, "Screen printing of nucleic acid detecting carbon electrodes," Analytical Chemistry, vol. 74, no. 17, pp. 4370-4377, 2002.

[40] G. A. Rivas, M. L. Pedano, and N. F. Ferreyra, "Electrochemical biosensors for sequence-specific DNA detection," Analytical Letters, vol. 38, no. 15, pp. 2653-2703, 2005.

[41] M. Mehrvar and M. Abdi, "Recent developments, characteristics, and potential applications of electrochemical biosensors," Analytical Sciences, vol. 20, no. 8, pp. 1113-1126, 2004.

[42] J. P. Hart, A. Crew, E. Crouch, K. C. Honeychurch, and R. M. Pemberton, "Some recent designs and developments of screen-printed carbon electrochemical sensors/biosensors for biomedical, environmental, and industrial analyses," Analytical Letters, vol. 37, no. 5, pp. 789-830, 2005.

[43] H. Ju and H. Zhao, "Electrochemical biosensors for DNA analysis," Frontiers in Bioscience, vol. 10, no. 1, pp. 37-46, 2005.

[44] K. Kerman, M. Kobayashi, and E. Tamiya, "Recent trends in electrochemical DNA biosensor technology," Measurement Science and Technology, vol. 15, no. 2, pp. R1-R11, 2004.

[45] F. Lucarelli, L. Authier, G. Bagni, et al., "DNA biosensor investigations in fish bile for use as a biomonitoring tool," Analytical Letters, vol. 36, no. 9, pp. 1887-1901, 2003.

[46] J. Wang, G. Rivas, D. Luo, X. Cai, F. S. Valera, and N. Dontha, "DNA-modified electrode for the detection of aromatic amines," Analytical Chemistry, vol. 68, no. 24, pp. 4365-4369, 1996.

[47] J. Wang, J. M. Chicarro, G. Rivas, et al., "DNA biosensor for the detection of hydrazines," Analytical Chemistry, vol. 68, no. 13, pp. 2251-2254, 1996.

[48] G. Chiti, G. Marrazza, and M. Mascini, "Electrochemical DNA biosensor for environmental monitoring," Analytica Chimica Acta, vol. 427, no. 2, pp. 155-164, 2001.

[49] A. Erdem and M. Ozsoz, "Interaction of the anticancer drug epirubicin with DNA," Analytica Chimica Acta, vol. 437, no. 1, pp. 107-114, 2001

[50] F. Lucarelli, A. Kicela, I. Palchetti, G. Marrazza, and M. Mascini, "Electrochemical DNA biosensor for analysis of wastewater samples," Bioelectrochemistry, vol. 58, no. 1, pp. 113-118, 2002.

[51] F. Lucarelli, I. Palchetti, G. Marrazza, and M. Mascini, "Electrochemical DNA biosensor as a screening tool for the detection of toxicants in water and wastewater samples," Talanta, vol. 56, no. 5, pp. 949-957, 2002.
[52] V. C. Diculescu, A.- M. C. Paquim, and A. M. O. Brett, "Electrochemical DNA sensors for detection of DNA damage," Sensors, vol. 5, no. 6-10, pp. 377-393, 2005.

[53] J. Labuda, K. Bubnicova, L. Kovalova, M. Vanickova, J. Mattusch, and R. Wennrich, "Voltammetric detection of damage to DNA by arsenic compounds at a DNA biosensor," Sensors, vol. 5, no. 6-10, pp. 411-423, 2005.

[54] G. Bagni, D. Osella, E. Sturchio, and M. Mascini, "Deoxyribonucleic acid (DNA) biosensors for environmental risk assessment and drug studies," Analytica Chimica Acta, vol. 573574, pp. 81-89, 2006.

[55] G. Marrazza, G. Chiti, M. Mascini, and M. Anichini, "Detection of human apolipoprotein E genotypes by DNA electrochemical biosensor coupled with PCR," Clinical Chemistry, vol. 46, no. 1, pp. 31-37, 2000.

[56] C. A. Rabik and M. E. Dolan, "Molecular mechanisms of resistance and toxicity associated with platinating agents," Cancer Treatment Reviews, vol. 33, no. 1, pp. 9-23, 2007.

[57] V. Brabec and J. Kasparkova, "Modifications of DNA by platinum complexes: relation to resistance of tumors to platinum antitumor drugs," Drug Resistance Updates, vol. 8, no. 3, pp. 131-146, 2005.

[58] A. Cagnini, I. Palchetti, I. Lionti, M. Mascini, and A. P. F. Turner, "Disposable ruthenized screen-printed biosensors for pesticides monitoring," Sensors and Actuators B, vol. 24, no. 13, pp. 85-89, 1995.

[59] G. Bagni, M. Ravera, D. Osella, and M. Mascini, "Electrochemical biosensors as a screening tool of in vitro DNA-drug interaction," Current Pharmaceutical Analysis, vol. 1, no. 3, pp. 217-224, 2005.

[60] G. Bagni, DNA biosensors for environmental risk assessment and drug studies, Ph.D. thesis, University of Florence, Florence, Italy, 2005.

[61] M. L. Pedano and G. A. Rivas, "Immobilization of DNA on glassy carbon electrodes for the development of affinity biosensors," Biosensors and Bioelectronics, vol. 18, no. 2, pp. 269-277, 2003.

[62] V. Cai, G. Rivas, P. A. M. Farias, H. Shiraishi, J. Wang, and E. Paleček, "Evaluation of different carbon electrodes for adsorptive stripping analysis of nucleic acids," Electroanalysis, vol. 8, no. 8-9, pp. 753-758, 1996.

[63] C. Xia, G. Shen, J. Jiang, and R. Yu, "Intercalation of pharmorubicin anticancer drug to DNA studied by cyclic voltammetry with analytical applications," Analytical letters, vol. 32, no. 4, pp. 717-727, 1999.

[64] M. Ravera, S. Baracco, C. Cassino, et al., "Electrochemical measurements confirm the preferential bonding of the antimetastatic complex $[\mathrm{ImH}]\left[\mathrm{RuCl}_{4}(\mathrm{DMSO})(\mathrm{Im})\right]$ (NAMI-A) with the proteins and the weak interaction with nucleobases," Inorganic Biochemistry, vol. 98, pp. 984-990, 2004.

[65] M. Mascini, G. Bangi, M. L. Di Pietro, M. Ravera, S. Baracco, and D. Osella, "Electrochemical biosensor evaluation of the interaction between DNA and metallo-drugs," Biometals, vol. 19, no. 4, pp. 409-418, 2006.

[66] S. J. Berners-Price and T. G. Appleton, "The chemistry of cisplatin in aqueous solution," in Platinum-Based Drugs in Cancer Therapy, L. R. Kelland, Ed., pp. 3-35, Humana Press, Totowa, NJ, USA, 2000.

[67] P. M. Takahara, C. A. Frederick, and S. J. Lippard, "Crystal structure of the anticancer drug cisplatin bound to duplex DNA," The American Chemical Society, vol. 118, no. 49, pp. 12309-12321, 1996.

[68] P. M. Takahara, A. C. Rosenzweig, C. A. Frederick, and S. J. Lippard, "Crystal structure of double-stranded DNA 
containing the major adduct of the anticancer drug cisplatin," Nature, vol. 377, no. 6550, pp. 649-652, 1995.

[69] A. P. Silverman, W. Bu, S. M. Cohen, and S. J. Lippard, " $2.4-\AA$ crystal structure of the asymmetric platinum complex $\{\mathrm{Pt}(\text { ammine }) \text { (cyclohexylamine) }\}^{2+}$ bound to a dodecamer DNA duplex," The Journal of Biological Chemistry, vol. 277, no. 51, pp. 49743-49749, 2002.

[70] M. A. Jakupec, M. Galanski, and B. K. Keppler, "Tumourinhibiting platinum complexes-state of the art and future perspectives," Reviews of Physiology Biochemistry and Pharmacology, vol. 146, pp. 1-53, 2003.

[71] W. Fery, J. D. Ranford, and P. J. Sadler, "Ring opening reactions of the anticancer drug carboplatin: NMR characterization of cis- $\left[\mathrm{Pt}\left(\mathrm{NH}_{3}\right)_{2}(\mathrm{CBDCA}-\mathrm{O})\left(5^{\prime} \mathrm{GMP}-\mathrm{N} 7\right)\right]$ in solution," Inorganic Chemistry, vol. 32, pp. 1333-1340, 1993.

[72] M. Cusumano, M. L. Di Pietro, and A. Giannetto, "Relationship between binding affinity for calf-thymus DNA of $\left[\operatorname{Pt}\left(2,2^{\prime}-\text { bpy }\right)(n-\mathrm{Rpy})_{2}\right]^{2+}(n=2,4)$ and basicity of coordinated pyridine," Chemical Communications, no. 22, pp. 25272528, 1996.

[73] D. P. Bancroft, C. A. Lepre, and S. J. Lippard, "Pt-195 NMR kinetics and mechanistic studies of cis-diamminedichloroplatinum and trans-diamminedichloroplatinum(II) binding to DNA," Journal of the American Chemical Society, vol. 112, pp. 6860-6871, 1990.

[74] O. Heudi, S. Mercier-Jobard, A. Cailleux, and P. Allain, "Mechanisms of reaction of L-methionine with carboplatin and oxaliplatin in different media: a comparison with cisplatin," Biopharmaceutics and Drug Disposition, vol. 20, no. 2, pp. 107116, 1999.

[75] J. Malina, O. Novakova, B. K. Keppler, E. Alessio, and V. Brabec, "Biophysical analysis of natural, double-helical DNA modified by anticancer heterocyclic complexes of ruthenium(III) in cell-free media," Journal of Biological Inorganic Chemistry, vol. 6, no. 4, pp. 435-445, 2001.

[76] E. Gallori, C. Vettori, E. Alessio, et al., "DNA as a possible target for antitumor ruthenium(III) complexes: a spectroscopic and molecular biology study of the interactions of two representative antineoplastic ruthenium(III) complexes with DNA," Archives of Biochemistry and Biophysics, vol. 376, no. 1, pp. 156-162, 2000.

[77] L. Messori, P. Orioli, D. Vullo, E. Alessio, and E. Iengo, "A spectroscopic study of the reaction of NAMI, a novel ruthenium(III) anti-neoplastic complex, with bovine serum albumin," European Journal of Biochemistry, vol. 267, no. 4, pp. 1206-1213, 2000.

[78] A. R. Timerbaev, C. G. Hartinger, S. S. Aleksenko, and B. K. Keppler, "Interactions of antitumor metallodrugs with serum proteins: advances in characterization using modern analytical methodology," Chemical Reviews, vol. 106, no. 6, pp. 22242248, 2006.

[79] G. Sava, E. Alessio, A. Bergamo, and G. Mestroni, "Sulfoxide ruthenium complexes: non-toxic tools for the selective treatment of solid tumour metastases," in Topics in Biological Inorganic Chemistry, Vol. 1: Metallopharmaceuticals I DNA Interactions, pp. 144-169, Springer, Berlin, Germany, 1999.

[80] L. Y. Kuo, A. H. Liu, and T. J. Marks, "Metallocene interactions with DNA and DNA-processing enzymes," Metal Ions in Biological Systems, vol. 33, pp. 53-85, 1996.

[81] G. Mokdsi and M. M. Harding, "Water soluble, hydrolytically stable derivatives of the antitumor drug titanocene dichloride and binding studies with nucleotides," Journal of Organometallic Chemistry, vol. 565, no. 1-2, pp. 29-35, 1998.
[82] M. M. Harding, G. Mokdsi, J. P. Mackay, M. Prodigalidad, and S. W. Lucas, "Interactions of the antitumor agent molybdocene dichloride with oligonucleotides," Inorganic Chemistry, vol. 37, no. 10, pp. 2432-2437, 1998.

[83] P. Köpf-Maier, "Intracellular localization of titanium within xenografted sensitive human tumors after treatment with the antitumor agent titanocene dichloride," Journal of Structural Biology, vol. 105, no. 1-3, pp. 35-45, 1990.

[84] M. Guo, Z. Guo, and P. Sadler, "Titanium(IV) targets phosphoesters on nucleotides: implications for the mechanism of action of the anticancer drug titanocene dichloride," Journal of Biological Inorganic Chemistry, vol. 6, no. 7, pp. 698-707, 2001.

[85] L. A. Zwelling, T. Anderson, and K. W. Kohn, "DNA-protein and DNA interstrand cross-linking by cis- and transplatinum(II) diamminedichloride in L1210 mouse leukemia cells and relation to cytotoxicity," Cancer Research, vol. 39, no. 2, part 1, pp. 365-369, 1979.

[86] R. J. Knox, F. Friedlos, D. A. Lydall, and J. J. Roberts, "Mechanism of cytotoxicity of anticancer platinum drugs: evidence that cis-diamminedichloroplatinum(II) and cis-diammine(1,1-cyclobutanedicarboxylato)platinum(II) differ only in the kinetics of their interaction with DNA," Cancer Research, vol. 46, no. 4, part 2, pp. 1972-1979, 1986.

[87] E. Lindauer and E. Holler, "Cellular distribution and cellular reactivity of platinum(II) complexes," Biochemical Pharmacology, vol. 52, no. 1, pp. 7-14, 1996.

[88] M. F. Pera Jr., C. J. Rawlings, and J. J. Roberts, “The role of DNA repair in the recovery of human cells from cisplatin toxicity," Chemico-Biological Interactions, vol. 37, no. 1-2, pp. 245261, 1981.

[89] A. B. Steel, T. M. Herne, and M. J. Tarlov, "Electrochemical quantitation of DNA immobilized on gold," Analytical Chemistry, vol. 70, no. 22, pp. 4670-4677, 1998. 


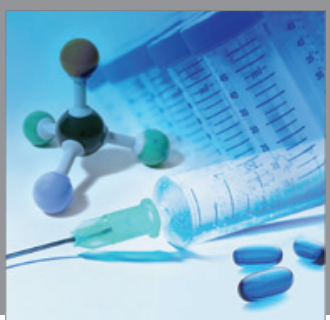

International Journal of

Medicinal Chemistry

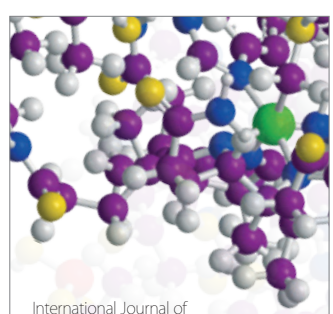

Carbohydrate Chemistry

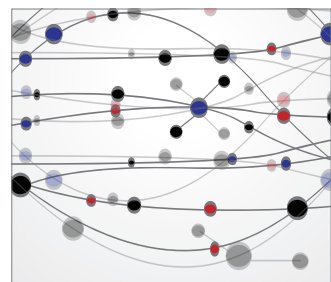

The Scientific World Journal
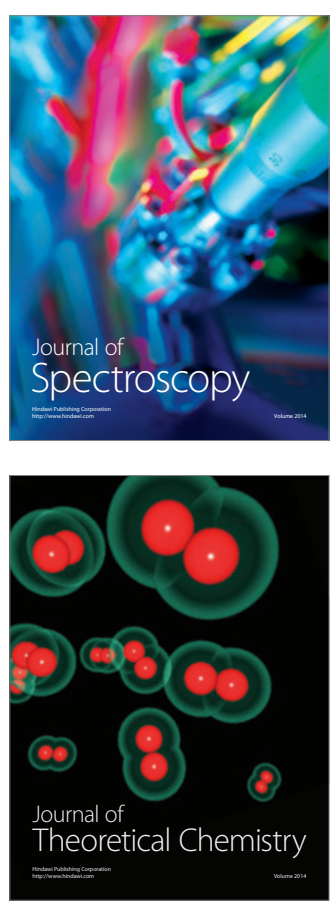
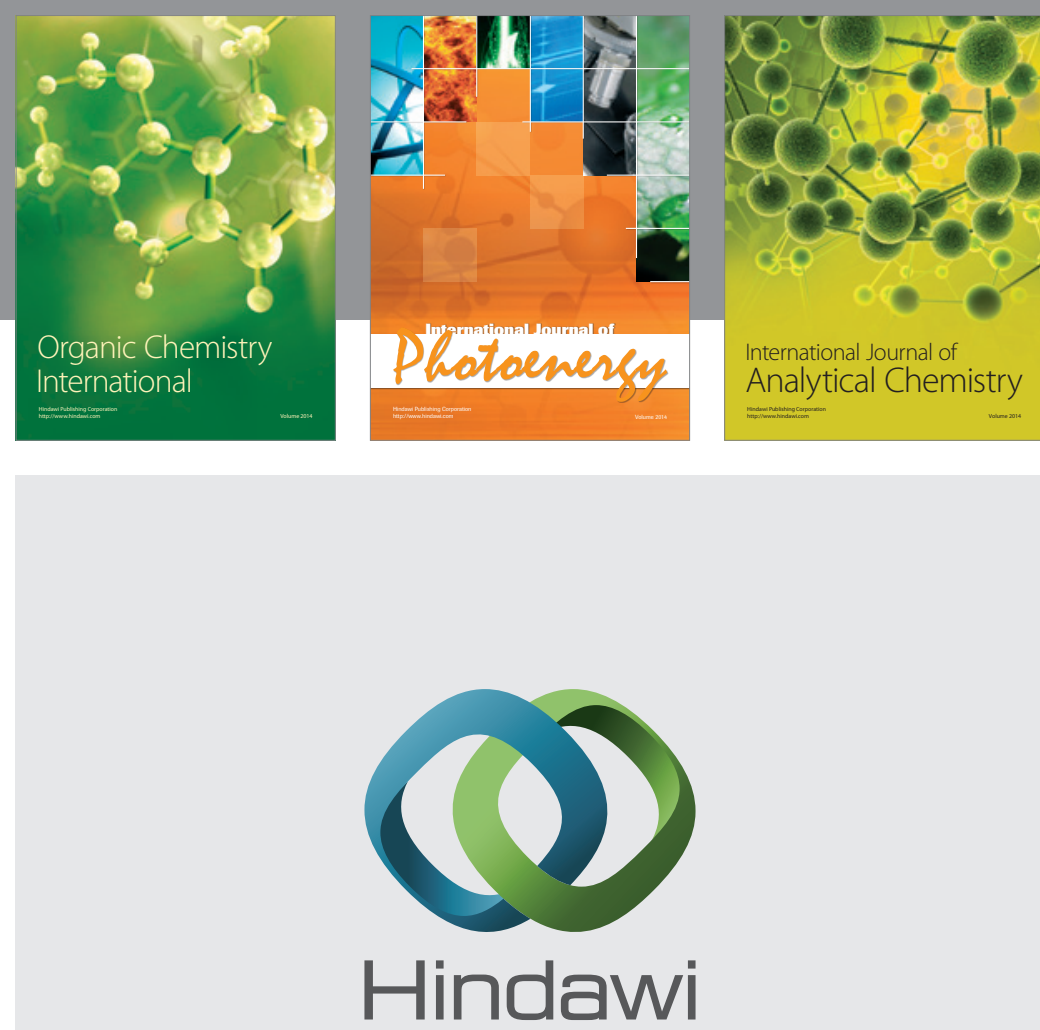

Submit your manuscripts at

http://www.hindawi.com
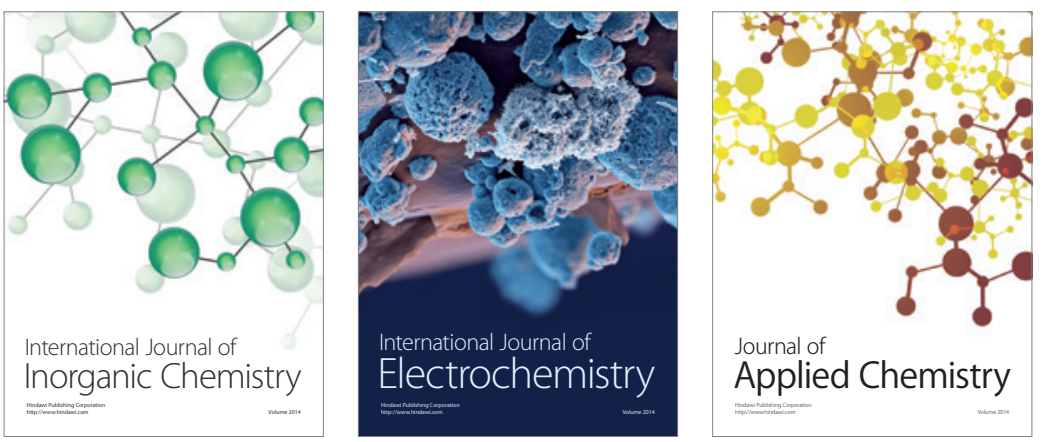

Journal of

Applied Chemistry
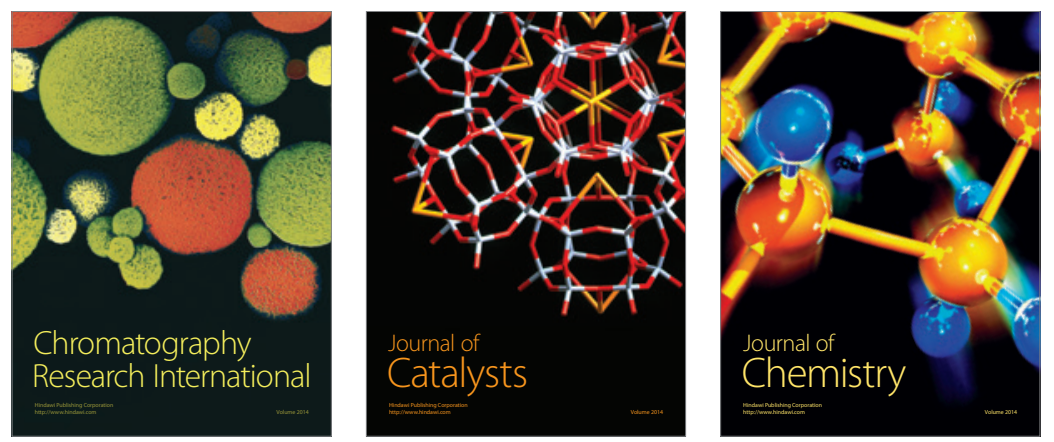
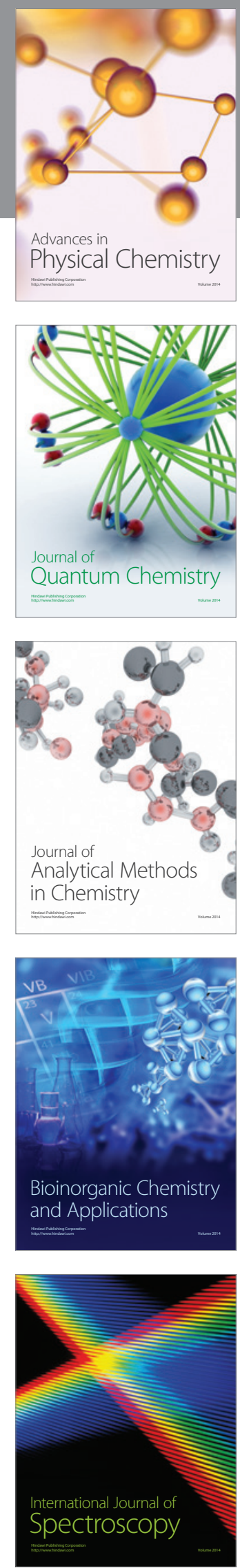